MISS TULSI PATEL (Orcid ID : 0000-0002-2797-1443)

Article type : Original Article

\title{
Running Title: Whole-exome sequencing of the BDR cohort: Evidence to support the role of the PILRA gene in Alzheimer's disease
}

Authors: Tulsi Patel ${ }^{1}$, Keeley J. Brookes ${ }^{1}$, James Turton ${ }^{1}$, Sultan Chaudhury ${ }^{1}$, Tamar GuettaBaranes $^{1}$, Rita Guerreiro ${ }^{2,3}$, Jose Bras ${ }^{2,3}$, Dena Hernandez ${ }^{4}$, Andrew Singleton ${ }^{4}$, Paul T. Francis $^{5}$, John Hardy ${ }^{2}$ and Kevin Morgan ${ }^{1}$

1. Human Genetics Group, University of Nottingham, Nottingham, UK

2. Department of Molecular Neuroscience, Institute of Neurology, University College London, London, UK; UK Dementia Research Institute at UCL (UK DRI), London, UK

3. Department of Medical Sciences, Institute of Biomedicine-iBiMED, University of Aveiro, Aveiro, Portugal

4. Laboratory of Neurogenetics, National Institute of Aging, National Institute of Health, Bethesda, MD, USA

5. Brains for Dementia Research Resource, Wolfson Centre for Age Related Diseases, King's College London, London, UK

Corresponding author: kevin.morgan@nottingham.ac.uk

Key words: Whole-exome sequencing, Alzheimer's disease, burden analysis, polygenic risk score

\section{Abstract}

Aim: Late-onset Alzheimer's disease (LOAD) accounts for $95 \%$ of all Alzheimer's cases and is genetically complex in nature. Overlapping clinical and neuropathological features between AD, FTD and Parkinson's disease highlight the potential role of genetic pleiotropy across diseases. Recent GWAS have uncovered 20 new loci for AD risk, however these exhibit small effect sizes. Using NGS, here we perform association analyses using exomewide and candidate-gene driven approaches.

This article has been accepted for publication and undergone full peer review but has not been through the copyediting, typesetting, pagination and proofreading process, which may lead to differences between this version and the Version of Record. Please cite this article as doi: 10.1111/nan. 12452

This article is protected by copyright. All rights reserved. 
Methods: Whole-exome sequencing was performed on $132 \mathrm{AD}$ cases and 53 control samples. Exome-wide single variant association and gene burden tests were performed for 76,640 non-singleton variants. Samples were also screened for known causative mutations in familial genes in $A D$ and other dementias. Single variant association and burden analysis was also carried out on variants in known $A D$ and other neurologic dementia genes.

Results: Tentative single variant and burden associations were seen in several genes with kinase and protease activity. Exome-wide burden analysis also revealed significant burden of variants in PILRA $\left(\mathrm{P}=3.4 \times 10^{-5}\right)$, which has previously been linked to $A D$ via GWAS, hit ZCWPW1. Screening for causative mutations in familial $A D$ and other dementia genes revealed no pathogenic variants. Variants identified in ABCA7, SLC24A4, CD33 and LRRK2 were nominally associated with disease $(\mathrm{P}<0.05)$ but did not withstand correction for multiple testing. APOE $(\mathrm{P}=0.02)$ and $C L U(\mathrm{P}=0.04)$ variants showed significant burden on $A D$.

Conclusions: In addition, polygenic risk scores (PRS) were able to distinguish between cases and controls with $83.8 \%$ accuracy using 3,268 variants, sex, age at death and APOE $\varepsilon 4$ and $\varepsilon 2$ status as predictors.

\section{Abbreviations}

$A D$

- Alzheimer's disease

AUC

- area under curve

BDR

- Brains for Dementia Research

DLB

- Dementia with Lewy bodies

fEOAD - familial early onset Alzheimer's disease

FTD $\quad-$ Frontotemporal dementia

GWAS - -genome-wide association study

LOAD - late onset Alzheimer's disease

MAF - minor allele frequency

NGS - next generation sequencing

OR - odds ratio

$\mathrm{P}$

- P-value

This article is protected by copyright. All rights reserved. 


$\begin{array}{ll}\text { PCR } & - \text { polymerase chain reaction } \\ \text { PD } & - \text { Parkinson's disease } \\ \text { PRS } & - \text { polygenic risk score }\end{array}$

\section{Introduction}

Alzheimer's disease (AD) is the most common form of dementia, affecting over 850,000 people in the UK alone, a number expected to rise to 1 million by 2025 [1]. There are two forms distinguished by the age when symptoms first appear. In the early-onset familial form (fEOAD), symptoms appear before 65 years of age, however this only accounts for about $5 \%$ of cases [2]. Mutations in the familial genes APP, PSEN1 and PSEN2 are rare but highly penetrant. Individuals with these mutations are almost certain to develop fEOAD [3]. The majority of cases are sporadic in nature and classified as late-onset (LOAD), with symptoms appearing at 65 years or later. This represents the other $95 \%$ of all incidences [4]. Presence of the $A P O E \& 4$ allele is the largest known genetic risk factor for LOAD, with a 2-3 fold increase in risk for carriers and 15 fold for individuals homozygous for the $\varepsilon 4$ allele [5]. The rare $\varepsilon 2$ allele confers a protective effect and appears to reduce AD risk by up to $40 \%$.

Genome-wide association studies (GWAS) have identified 20 risk variants associated with LOAD [6-9]; this has implicated several new pathways in AD, such as endocytic processing, inflammation and cholesterol transport [8]. Although highly replicable in Caucasian groups, these effects have been difficult to replicate in other populations [10]. These common variants also exert only small effects on disease risk, which does not account for much of the missing heritability in AD. It is likely that low frequency variants, not detected by GWAS, could have greater effect sizes and therefore explain more of the heritable component.

Advances in next-generation sequencing (NGS) in recent years have allowed exomes and entire genomes to be explored at single-base level. The exome accounts for approximately $1 \%$ of the human genome, yet it harbours almost $85 \%$ of known mutations underlying disease-related traits [11]. Therefore, rare mutations can be identified using this technology. Whole-exome sequencing (WES) has identified a rare variant in the TREM2 gene, $\mathrm{R} 47 \mathrm{H}$, associated with a 5 -fold increase in AD risk [12]. These studies have also found rare causative variants in CLU and SORL1 that were overlooked by GWAS [13]. By identifying the genetic variants of individuals, WES has the potential to uncover more rare variants associated with $A D$ risk.

This article is protected by copyright. All rights reserved. 
There are several overlapping clinical and neuropathological features across different dementias. For example, dementia with Lewy bodies (DLB) shares clinical features with AD and Parkinson's disease (PD), often resulting in misdiagnosis. PD and DLB are both synucleinopathies presenting with alpha-synuclein deposits in the brain, whereas APOE \&4 increases risk of disease in AD and DLB [14]. This suggests that genetic risk factors may contribute to more than one disease, known as genetic pleiotropy, whereby a gene or DNA variant can influence multiple phenotypes.

Clinically well-characterised brain tissue samples from healthy individuals remains a limiting factor in the study of neurological disorders [15], Brains for Dementia Research (BDR) (www.brainsfordementiaresearch.org.uk) is a network of six leading UK brain banks (jointly funded by Alzheimer's Research UK and Alzheimer's Society), specifically created to address the shortages of high-quality brain tissue samples from healthy individuals as well as those with dementia. This project is a planned brain donation programme with over 3000 participants, aged 65 years and above, with and without the diagnosis of dementia. Regular, standardised cognitive and psychiatric assessment of potential brain donors during life is critical in optimising the value of brain tissue for research $[16,17]$.

We performed single variant and burden analysis on coding variants to identify significant associations with LOAD. We also report on screening of 132 LOAD patients from the Brains for Dementia Research (BDR) resource with the aim to identify causative or predicted pathogenic coding variants in 40 selected genes. Of these, 16 are associated with familial forms of neurodegeneration, including fEOAD (APP, PSEN1 and PSEN2), frontotemporal dementia (FTD) and Amyotrophic lateral sclerosis (ALS) (C9or72, CHMP2B, FUS, GRN, MAPT, TARDBP and VCP), PD (LRRK2, PARK2, PARK7, PINK1 and SNCA) and Prion disease (PRNP). The remaining genes were selected from AD GWAS and NGS (20 GWAS, APOE and TREM2).

Polygenic risk scores (PRS) have been increasingly used to investigate the effect of multiple genetic variants on disease traits. It is based on the notion that many variants with small effects will not be detectable at genome-wide significance, however collectively they may have a strong effect [18]. PRS were generated to examine the association between multiple genetic markers and their collective effects on LOAD.

This article is protected by copyright. All rights reserved. 


\section{Materials and Methods}

\subsection{BDR samples}

The BDR cohort comprised of 132 clinically diagnosed LOAD (age at onset $\geq 65$ years) cases and 53 cognitively normal controls; all diagnoses were neuropathologically confirmed (Supplementary Table S1). Neuropathological diagnoses were undertaken by experienced neuropathologists within the Brains for Dementia Research network and were based on Thal $A \beta$ phases [19], neurofibrillary tangle Braak stages [20], Consortium to Establish a Registry for Alzheimer's disease (CERAD) criteria for AD [21] which are all combined in the National Institute on Aging - Alzheimer's Association guidelines [22], together with the Newcastle / McKeith criteria for Lewy body disease [23] and for FTLD-TDP as described by [24]. Whilst there are no fully established criteria for vascular pathology the VCING criteria were used [25] along with those proposed by Smallwood et al (2012) [26] and Grinberg and Thal (2010) [27].

Demographics of case and control samples for each centre are shown in Table 1. The average age at death was 82.5 years (range 65-101 years) for LOAD samples. For control individuals, average age at death was 85.9 years (range 58-104 years). The proportion of females between cases and controls were similar, accounting for around $50 \%$ of the total sample size. APOE \&4 carriers were 3-fold higher in cases (64.7\%) with almost one fifth (17.3\%) being homozygous for the $\varepsilon 4$ allele. In comparison only $24.5 \%$ of controls were carriers and no individuals were $\varepsilon 4 \varepsilon 4$. The $\varepsilon 2$ allele was present in 10 control samples (18.9\%) and 8 cases (6.2\%), with both a case and control sample being homozygous for the allele. The higher 3-fold frequency observed in control samples correlates with the protective effect of the $\varepsilon 2$ allele. All samples in the BDR cohort used for analysis were classified as AD or control by neuropathology.

The BDR has a number of neuropathological features available for more definitive analysis of genotype-phenotype correlation [28]. Data includes the CERAD scale, Braak tangle and Lewy body staging, with simplified measures (present/absent; mild/moderate/severe) of small vessel disease, deposition of TDP-43 protein, arteriolar A $3-C A A$ and cerebrovascular atherosclerosis. Detailed clinical and cognitive information on the samples is also available upon request, demonstrating the potential value of the BDR cohort for very detailed analyses in future studies as more extensive genetic data is generated.

\subsection{DNA extraction}

DNA was extracted from brain tissue using standard phenol-chloroform procedures.

Samples were analysed on the Agilent TapeStation and quantified using the Nanodrop 3300

This article is protected by copyright. All rights reserved. 
spectrometer to ensure high concentration and quality material was obtained. Samples were genotyped for $A P O E \varepsilon 2, \varepsilon 3$ and $\varepsilon 4$ alleles using the TaqMan method (Applied Biosystems) to determine $A P O E$ status.

\subsection{Exome sequencing library prep}

DNA libraries were hybridised to exome-capture probes with Agilent SureSelect Human All Exon Kit V4 for Illumina GA (Agilent Technologies) as per manufacturer's protocol. Exomeenriched libraries were sequenced on the Illumina HiSeq 2500 using 2 x 100bp paired end read cycles. The Agilent capture library includes 5' and 3' untranslated regions.

\subsection{Bioinformatics}

Paired-end sequence reads were aligned to the human reference genome build 19 (UCSC hg19) using Burrows-Wheeler Aligner [29]. Format conversion, indexing and removal of PCR duplicates were performed with Picard (www.picard.sourceforge.net/index.shtml). The Genome Analysis Toolkit was used for recalibration of base quality scores, realignment around indels and variant calling [30]. Variants were annotated using ANNOVAR [31] and Variant Effect Predictor [32] predicted SIFT and Polyphen2 scores of protein coding variants. Consistency between SIFT and Polyphen2 predictions and the databases allowed more reliable classification. Variants were also checked against established databases (dbSNP v.149, 1000 Genomes Project and Exome Variant Server).

\subsection{Filtering}

Singleton variants with MAF $\leq 0.002$ were removed in VCFtools [33]. Coding variants in genes were filtered by annotation with SnpSift [34]. Visualisation of variants was performed, when necessary, using Integrative Genomics Viewer [35]. Individuals with a calculated age at onset below 65 years were removed and samples were screened for causative mutations in fEOAD genes APP, PSEN1 and PSEN2 to ensure only sporadic cases were used for analyses. Pathogenicity of variants was determined using pathogenic status in AD\&FTD and PD mutation databases [36].

\subsection{Association analyses}

Quality control filtering was performed on the VCF using VCFtools. Individuals were removed if genotyping rate $\leq 97 \%$, followed by markers with call rate $\leq 98 \%$. Markers with significant deviation $(\mathrm{P}<0.001)$ from the Hardy-Weinberg equilibrium in control individuals were removed. After removing samples and markers failing quality control, 290 individuals remained with 76,640 non-singleton variants in coding regions. The average genotyping rate was $99.9 \%$.

This article is protected by copyright. All rights reserved. 
Plink files were imported to PLINK-SEQ [37] (https://atgu.mgh.harvard.edu/plinkseq/). Single-variant association was performed on samples using a logistic regression test correcting for the covariates sex, age at death and $A P O E \varepsilon 4$ allele count.

Gene-based association for genes of interest was calculated in R using a SKAT-O [38] burden test. The C-alpha test was used for exome-wide analysis and the SKAT-O test was used for selected genes.

\subsection{Polygenic risk scoring}

PRS were generated for BDR samples using PRSice [39]. The International Genomics of Alzheimer's Project (IGAP) summary data was used as the base dataset, collated from 17,008 LOAD cases and 37,154 controls. A region of 500kb around the APOE locus was excluded from the analysis. The best-fit model with the greatest predictive accuracy was computed using area under the curve (AUC) in SPSS. Additional predictor variables included were the number of $A P O E \varepsilon 4$ and $\varepsilon 2$ alleles, age, sex and genotypes for the GWAS SNPs.

\section{Results}

\subsection{Overview of data}

Exome-sequencing was performed on a total of 292 individuals. The final cohort consisted of 132 LOAD cases and 53 control samples after quality control filtering. A total of 157,217 non-singleton variants were present in 290 individuals, with a minimum of 2 alleles observed per variant. Filtering to retain only coding mutations resulted in 76,640 variants for exomewide analysis.

\subsection{Exome-wide analyses}

Burden analysis using a C-alpha test highlighted some nominally significant gene associations with $\mathrm{AD}$, shown in Table 2. PILRA and PRSS45 are just below the Bonferronicorrected threshold $\left(\mathrm{P}=2 \times 10^{-6}\right)$ at $\mathrm{P}=3.4 \times 10^{-5}$ and $\mathrm{P}=5.9 \times 10^{-5}$, respectively. $P$ ILRA has previously been linked to AD through ZCWPW1, which was highlighted by the GWAS metaanalysis [9]. Five variants in PILRA contribute to the effect: intronic variants rs7792525, rs190071731 and rs148891131, synonymous mutation rs2405442 and missense variant p.S279L (rs34266222). GWAS SNP rs1476679 is in weak LD with rs2405442 $\left(R^{2}=0.50\right)$. This mutation is tolerated as predicted by SIFT and Polyphen2. The other genes have not previously been linked to AD. PRSS45 contains 5 variants that drive this signal, of which 2 were highly associated with disease (Table 3), therefore it is possible that these SNPs are contributing to the signal.

This article is protected by copyright. All rights reserved. 
Exome-wide association analysis was performed on the non-singleton variants, correcting for age, sex and APOE $\varepsilon 4$ status of individuals. As expected, APOE SNP rs429358 showed the most significant association prior to adjusting for covariates $\left(P=7.2 \times 10^{-9}, O R=6.5[3.2-\right.$ 13.1]). There were no significant associations at the genome-wide threshold $\left(P=5 \times 10^{-8}\right)$ or at the suggestive threshold $\left(P=1 \times 10^{-5}\right)$ after correction. However due to low sample numbers, we do not have the power to detect any association at that level. Some tentative associations were observed and are shown in Table 3.

Several of the genes encompassing variants are involved in signaling pathways, including serine proteases PRSS42 and PRSS45 and inositol triphosphate receptor ITPR3. SIFT and Polyphen2 predictions indicate that most mutations are benign or tolerated. However missense mutations TMEM260 p.A245S/T (rs17776256) and AVPR1B p.K65N (rs35369693) were predicted to be probably damaging by both software. Both variants are more frequent in control samples, signifying a protective effect. $M E P 1 B$ is a metalloprotease recently implicated in APP cleavage and has been implicated in inflammation. The synonymous variant p.S537 (rs173032) has an odds ratio of 3.1 (1.6-5.9) and has a significantly greater frequency in cases than controls, inferring an association with $A D$. Two missense mutations in PRSS45 are associated with protection against AD, p.I190L (rs58830807) and P130Q (rs58943210) however both are predicted to be benign. None of the genes aside from $M E P 1 B$ have been directly linked to dementia.

\subsection{Polygenic risk scoring}

A 500kb region around the $A P O E$ gene containing 227 variants was excluded from the analysis to identify effects independent of $A P O E$. The predictive accuracy of each tested model is given in Table 4, denoted by area under the curve (AUC), with $95 \%$ confidence intervals. The APOE $\varepsilon 4$ allele alone has $71.8 \%$ accuracy in discriminating between cases and controls, however this is a poor fit model. Other covariates $\varepsilon 2$, age, sex and GWAS greatly increase the predictive power $83.0 \%$. In total 3,268 variants were utilised to score risk of developing $A D$ using the best fit model, which had a predictive accuracy of $83.8 \%$ when combined with all covariates as predictors. The addition of PRS only increased this accuracy by $0.8 \%$, which is similar to improvements seen in other studies. There is overlap between scores for both groups, however on average scores were higher for cases. Mean scores for $\mathrm{AD}$ cases were $3.6 \times 10^{-4}$ compared to $2.7 \times 10^{-4}$ for control samples.

\subsection{Screening for familial mutations}

Samples were screened for mutations in fEOAD genes to remove any non-sporadic cases. $A$ total of 6 coding variants were found in APP (1), PSEN1 (1) and PSEN2 (4), shown in Table 5. All individuals were heterozygous for the variants listed and mutations were synonymous

This article is protected by copyright. All rights reserved. 
except two identified as missense. PSEN1 p.E318G (rs17125721) was classified as a risk modifier but not pathogenic, found in 5 cases and 1 control sample. PSEN2 p.S130L (rs63750197) was previously identified as possibly damaging in silico with unclear pathogenicity, present in 1 case and 1 control. Both SNPs were predicted to be deleterious depending on the transcript. However, no causative or fully penetrant pathogenic mutations were observed in these genes, confirming that these samples are representative of sporadic AD.

Other known neurologic genes were also screened for potential pathogenic mutations to identify genetic overlap between sporadic LOAD and other neurodegenerative diseases (Table 6). Mutations in Parkinson's genes LRRK2, PARK2 and PINK1 appear to have some possibly damaging consequences on the proteins. PARK2 p.R275W (rs34424986) is very rare and present in $1 \mathrm{AD}$ case and 1 control sample with mild cerebral amyloid angiopathy and presence of an unspecified dementia. SIFT/Polyphen2 predictions both indicate a potentially deleterious effect of this mutation. Variant p.P246L (rs149953814) was also found in 1 case and control, both also presenting with mild non-amyloid small vessel disease. Samples were heterozygous for both variants.

Previously uncharacterised mutations were found in $C H M P 2 B$ and $L R R K 2$. The frameshift variant in $C H M P 2 B$ was seen in a healthy control and an individual with $A D$. The $L R R K 2$ mutation was heterozygous in a sample of each phenotype and results in a p.L1271P change. PRNP p.M129V (rs1799990) has previously been implicated as a risk factor for prion disease, here however it is observed in an equal number of case and controls, suggesting no effect in AD.

\subsection{Association analyses of known neurologic genes}

Following on from this, genes were selected based on whether they had been linked to $A D$ or other neurological diseases. Direct functionality was inferred from data filtered for coding variants only. A total of 76,640 variants were annotated as coding mutations, with 219 variants in 35 of the selected genes. Association and burden analyses were performed as before on the subset of variants. No coding variants were identified in AD genes $H L A-D R B 1$, HLA-DRB5 and MEF2C or the other neurologic genes MAPT and TARDBP.

We performed single variant association on all 219 variants in the selected genes. No variants reached genome-wide or suggestive levels of significance as identified by a logistic regression test with correction for covariates. The most significant associations $(P<0.05)$ are listed in Table 7. Results for all 219 variants are shown in supplementary Table S2.

A large proportion of the highly associated variants are synonymous mutations. Four $A B C A 7$

This article is protected by copyright. All rights reserved. 
variants are present, with 2 suggesting increased risk $(O R>1)$ and 2 showing a protective effect $(\mathrm{OR}<1)$. $A B C A 7 \mathrm{rs} 3752234$ and rs3752237 are both synonymous mutations that increase risk more than 2 -fold. SLC24A4 synonymous SNP (rs7144273) also showed strong effects in the risk direction $(\mathrm{OR}=1.63, \mathrm{P}=0.018)$.

The majority of variants appear to be exhibiting a protective effect as indicated by the odds ratios, as they were observed more frequently in control samples. LRRK2 p.M1646T (rs35303786) missense is predicted as benign, however it is found in a greater frequency in control samples ( $\mathrm{OR}=0.14, \mathrm{P}=0.018)$. We calculated gene-based burden using a SKAT-O test to provide greater statistical power than that of a single-marker test (Table 8). Both sets of familial genes did not appear to exhibit any burden on LOAD. Burden analysis revealed two significant associations; $A P O E$ and $C L U$ were the only genes to reach significance $(P \leq 0.05)$. However, they would not pass Bonferroni correction $(P=0.0014)$. Five variants in $C L U$ contributed to the effect seen, which was corrected for age, sex and APOE \&4 status. Two of these variants were significant, synonymous variant rs9331939 and rs149859119 (p.S16R), therefore they could be driving the signal in this gene.

\section{Discussion}

In this study, we initially investigated genetic association with LOAD using an exome-wide approach. Although the analyses did not find any significant associations when corrected for multiple testing, the sample size only provides enough power to detect common variant (MAF>5\%) associations with an effect size above 2.2 with $80 \%$ certainty. Nonetheless, single variant analysis highlighted some interesting tentative associations which may merit further exploration.

Burden analysis revealed a tentative association with PILRA, an inhibitory immunoglobulin receptor involved in regulating signal transduction in the immune system. This gene has previously been linked to $A D$ via its interaction with paired activation receptor PILRB and GWAS hit ZCWPW1. It is expressed on myeloid cells and works with PILRB, which also associates with DAP12 and TREM2 [40]. PILRA SNP rs2405442 is in weak LD $\left(r^{2}=0.5\right)$ with GWAS SNP rs1476679, suggesting this signal is likely to be independent of the GWAS association. ZCWPW1 locus SNP rs1476679 was nominally associated with reduced PILRA levels [41]. This suggests a potential role for the gene in $A D$, highlighting the need for further investigation.

Many of the remaining genes on the burden list are enzymes with serine/threonine activity or serine proteases, such as PRSS45, BCR, KLK2 and THNSL2. Efficient breakdown of proteins is important as impairments in this can lead to the buildup of misfolded proteins.

This article is protected by copyright. All rights reserved. 
Dysfunction of the amyloid protein degradation pathway has been implicated in AD. None of these genes have been previously linked to AD. However in combination, enzymes regulating protein function and breakdown could play a greater role in disease and this too warrants further exploration.

Multiple PRSS45 variants were observed, with two missense mutations found to be associated with $A D$, exerting a protective effect. However, functional predictions indicate that both polymorphisms are benign. This gene encodes a serine protease, part of a group of enzymes that cleave peptide bonds. PRSS45 SNPs were also highly associated when tested in burden. Missense variants TMEM260 p.A245S and AVPR1B p.K65N were both predicted to be damaging to the protein in silico and found more frequently in control samples. The function of TMEM260 is not clearly understood, whereas AVPR1B is a vasopressin receptor located in the anterior pituitary gland that stimulates $A C T H$ release. AVPR1B SNP rs35369693 has been linked to mood disorders and found more frequently in affected females [42]. The mutation in MEP1B, known as meprin $\beta$ is synonymous; recent proteomic studies have found that these metalloproteases can cleave APP, affecting A $\beta$ levels $[43,44]$. While these associations are tentative, examination of other larger datasets could be worthwhile.

PRS generated for individuals showed that, on average, scores were significantly higher in LOAD cases than controls, despite an overlap amongst the cohort. Using sex, age at death, $A P O E \varepsilon 4$ and $\varepsilon 2$ allele counts and GWAS SNP genotypes as variables for prediction, the model was able to distinguish cases and control with $83.8 \%$ accuracy. A total of 3,268 variants were used to predict disease risk. The presence of controls with high risk scores suggests that these individuals may have gone on to develop $A D$ had they lived longer. The utility of PRS has already been demonstrated in AD, with individuals' genetic risk profiles able to predict disease susceptibility with more than $80 \%$ accuracy [45]. However, there were controls with high PRS and no phenotypic changes indicative of dementia and also cases with low PRS. Although PRS can identify more of the genetic component of $A D$, this shows that there is still unexplained missing heritability.

Mutations in familial AD genes, APP, PSEN1 and PSEN2 are rare but highly penetrant. Screening of these genes revealed no pathogenic variants and samples harbouring mutations were heterozygotes, confirming there were no familial EOAD cases amongst the BDR LOAD classified cases. Other neurologic familial genes were also screened for pathogenic mutations linked to related dementias. No known causative mutations were identified, however PARK2 p.R275W was predicted to be deleterious and has unknown pathogenicity in the PD mutation database. It produces an unusual distribution of parkin with large cytoplasmic and nuclear inclusions [46]. The variant was present in one case and

This article is protected by copyright. All rights reserved. 
control sample, however, which suggests that it is likely benign and not pathogenic in nature. Previously uncharacterised mutations were identified in $C H M P 2 B$ and $L R R K 2$, with a frameshift variant in $C H M P 2 B$ and a missense variant in $L R R K 2$. The frameshift variant was only seen in one control sample, suggesting that it could be a sequencing artifact. LRRK2 p.L1271P is present in a case and control sample so does not appear to segregate with disease. PRNP p.M129V has been highlighted as a risk factor for prion disease but appears not to be having any effect in AD.

TREM2 mutation p.R47H was observed in $3 \mathrm{AD}$ case samples which were heterozygotes. This variant can increase risk of developing AD by $2-3$ fold $[12,47]$. DNA was available for these 3 samples and Sanger sequencing confirmed the presence of the variant in these subjects. No control samples harboured this variant. However, given the documented frequency of $\mathrm{R} 47 \mathrm{H}(\mathrm{MAF}=0.002)$ this cohort appears to have a greater MAF of 0.008 . This 4fold greater frequency will be verified as the BDR sample set increases in size.

Single variant association of all neurologic gene variants revealed several synonymous mutations to be nominally associated with $A D$ at $P \leq 0.05$. The majority of variants exerted effects in the protective direction with greater frequency in controls than case samples. Four $A B C A 7$ variants were significantly associated at $\mathrm{P}<0.05$ with 2 increasing risk and 2 being protective. Synonymous variants rs3752234 and rs3752237 increased AD risk more than 2fold, which is contradictory to previous findings $[48,49]$, where the effects were protective. Conversely, rs4147915 and missense mutation rs3764645 p.E188G are protective. ABCA7 p.E188G is predicted as tolerated and previously shown to have no effect on disease risk [48]. These findings need to be validated as the sample size increases.

Missense variant $L R R K 2$ p.M1646T was associated with protection against $A D$, but the amino acid substitution is predicted to be tolerated. However the mutation is known to increase risk of developing PD [50]. LRRK2 mutations have previously been linked to AD with $P D$ risk variant p.R1628P found in greater frequencies in $A D$ cases than controls [51]. The variant increased apoptosis and cell death in transfected human cell lines. Therefore, it is likely that genetic pleiotropy possibly occurs across several neurodegenerative diseases. $L R R K 2$ is involved in autophagy and recycling proteins in the retrograde trafficking pathway. Mutations in this protein are associated with dendrite shortening in neurons, a possible cause of motor symptoms in PD [46]. With some shared clinical features, mutations in $L R R K 2$ could also affect the autophagy process in AD.

This article is protected by copyright. All rights reserved. 
Gene-based burden analysis in SKAT-O allowed adjustment to correct for the effect of age, sex and number of $A P O E \varepsilon 4$ alleles. Both $A D$ and other neurologic familial genes did not exhibit any burden on LOAD. APOE and CLU were significant to $\mathrm{P}<0.05$ but did not pass Bonferroni correction. Only SNP p.S16R in CLU was significantly associated in single variant testing, indicating that this is driving the signal.

\section{Conclusion}

Although other familial neurologic genes did not show any burden on LOAD, an individual missense variant in $L R R K 2$ was tentatively associated; preliminary exploration of the data has indicated that genetic pleiotropy is likely to play a role in diseases with overlapping features. LRRK2 is involved in PD, yet few studies have investigated its role in other dementias.

Exome-wide analysis has revealed a significant burden of PILRA variants on AD. Previous studies have identified a possible link with $A D$ via GWAS hit ZCWPW1 and paired receptor PILRB which associates with DAP12 and TREM2. PILRA and PILRB function may be coregulated and therefore further investigation should involve looking at both genes in AD.

Limitations in power have made it difficult to find many significant associations, but with ongoing data collection, the sample size will increase to address this issue. However, using an exome sequencing approach it has been possible to detect rare variants with greater effect sizes, which previous GWAS did not permit.

\section{Supplementary Information}

Supplementary Table S1. Summary data of all case and control samples used for analysis. Supplementary Table S2. Variants found in AD-related genes in 129 LOAD cases and 53 controls.

\section{Acknowledgements}

We would like to gratefully acknowledge all donors and their families for the tissue provided for this study. Human post-mortem tissue was obtained from the South West Dementia Brain Bank, London Neurodegenerative Diseases Brain Bank, Manchester Brain Bank, Newcastle Brain Tissue Resource and Oxford Brain Bank, members of the Brains for Dementia Research (BDR) Network. The BDR is jointly funded by Alzheimer's Research UK and the Alzheimer's Society in association with the Medical Research Council.

This article is protected by copyright. All rights reserved. 
We also wish to acknowledge the neuropathologists at each centre and BDR Brain Bank staff for the collection and classification of the samples. The South West Dementia Brain Bank is part of the Brains for Dementia Research program, jointly funded by Alzheimer's Research UK and Alzheimer's Society, and is supported by BRACE (Bristol Research into Alzheimer's and Care of the Elderly) and the Medical Research Council. We thank the donor whose donation of brain tissue to the London Neurodegenerative Diseases Brain Bank allowed this work to take place. The Brain Bank is supported by the Medical Research Council and Brains for Dementia Research (jointly funded by the Alzheimer's Society and Alzheimer's Research UK). We acknowledge the support of the Manchester Brain Bank by Alzheimer's Research UK and Alzheimer's Society through their funding of the Brains for Dementia Research (BDR) Programme. Manchester Brain Bank also receives Service Support costs from Medical Research Council. Tissue provided by the Newcastle Brain Tissue Resource is funded in part by a grant from the UK Medical Research Council (G0400074), by NIHR Newcastle Biomedical Research Centre and Unit awarded to the Newcastle upon Tyne NHS Foundation Trust and Newcastle University, and by a grant from the Alzheimer's Society and Alzheimer's Research UK as part of the Brains for Dementia Research Project. Tissue for this study was provided by the Newcastle Brain Tissue Resource, which is funded in part by a grant from the UK Medical Research Council (G0400074) and by Brains for Dementia research, a joint venture between Alzheimer's Society and Alzheimer's Research UK. We acknowledge the Oxford Brain Bank, supported by the UK MRC, the NIHR Oxford Biomedical Research Centre and the Brains for Dementia Research programme for providing post-mortem specimens.

Jose Bras and Rita Guerreiro's work is funded by Fellowships from the Alzheimer's Society. The Nottingham research group is supported by funding from ARUK.

We thank the International Genomics of Alzheimer's Project (IGAP) for providing summary results data for these analyses. The investigators within IGAP contributed to the design and implementation of IGAP and/or provided data but did not participate in analysis or writing of this report. IGAP was made possible by the generous participation of the control subjects, the patients, and their families. The i-Select chips were funded by the French National Foundation on Alzheimer's disease and related disorders. EADI was supported by the LABEX (laboratory of excellence program investment for the future) DISTALZ grant, Inserm, Institut Pasteur de Lille, Université de Lille 2, and the Lille University Hospital. GERAD was supported by the Medical Research Council (Grant $n^{\circ}$ 503480), Alzheimer's Research UK (Grant $n^{\circ}$ 503176), the Wellcome Trust (Grant no. 082604/2/07/Z) and German Federal Ministry of Education and Research (BMBF): Competence Network Dementia (CND) grant no. 01GI0102, 01GI0711, 01GI0420. CHARGE was partly supported by the NIH/NIA grant R01 AG033193 and the NIA AG081220 and AGES contract N01-AG-12100, the NHLBI 
grant R01 HL105756, the Icelandic Heart Association, and the Erasmus Medical Center and Erasmus University. ADGC was supported by the NIH/NIA grants: U01 AG032984, U24 AG021886, U01 AG016976, and the Alzheimer's Association grant ADGC-10-196728.

This work was supported in part by the Intramural Research Program of the National Institute on Aging, National Institutes of Health, part of the Department of Health and Human Services; project ZO1 AG000950.

Tulsi Patel is the recipient of a PhD studentship from Neuroscience Support Group (NSG) and University of Nottingham.

There are no conflicts of interest.

\section{Author Contributions:}

Tulsi Patel - data generation, analysis, manuscript preparation

Keeley J. Brookes - data collection, critiqued manuscript

James Turton - analysis, critiqued manuscript

Sultan Chaudhury - analysis, critiqued manuscript

Tamar Guetta-Baranes - sample preparation, critiqued manuscript

Rita Guerreiro - data generation, critiqued manuscript

Jose Bras - data generation, critiqued manuscript

Dena Hernandez - data generation, critiqued manuscript

Andrew Singleton - data generation, critiqued manuscript

Paul T. Francis - sample contribution, critiqued manuscript

John Hardy - study design, study supervision and management, critiqued manuscript

Kevin Morgan - study design, study supervision and management, data generation, analysis, manuscript preparation

\section{Approval}

Written informed consent was obtained for all individuals and approved by the appropriate institutional review boards (BDR ethics number 08/H0704/128 + 5).

\section{References}

1. Alzheimer's Society. Drug treatments for Alzheimer's disease. Natl Inst Heal Care Excell. 2014;1-13.

2. Minati L, Edginton T, Bruzzone MG, Giaccone G. American Journal of Alzheimer 's

This article is protected by copyright. All rights reserved. 
Disease and Other Dementias Current Concepts in Alzheimer's Disease : A Multidisciplinary Review. 2009;95-121.

3. Bertram L, Lill CM, Tanzi RE. The genetics of Alzheimer's disease: Back to the future. Neuron. 2010;68(2):270-81.

4. Piaceri I, Nacmias B, Sorbi S. Genetics of familial and sporadic Alzheimer's disease. Front Biosci (Elite Ed). 2013 Jan 1;5:167-77.

5. Farrer LA, Cupples LA, Haines JL, Hyman B, Kukull WA, Mayeux R, Myers RH, Pericak-Vance MA, Risch N, Duijn CM van. Effects of Age, Sex, and Ethnicity on the Association Between Apolipoprotein E Genotype and Alzheimer Disease. JAMA. 1997 Oct 22;278(16):1349.

6. Harold D, Abraham R, Hollingworth P, Sims R, Gerrish A, Hamshere ML, Pahwa JS, Moskvina V, Dowzell K, Williams A, Jones N, Thomas C, Stretton A, Morgan AR, Lovestone S, Powell J, Proitsi P, Lupton MK, Brayne C, Rubinsztein DC, Gill M, Lawlor B, Lynch A, Morgan K, Brown KS, Passmore PA, Craig D, McGuinness B, Todd S, Holmes C, Mann D, Smith AD, Love S, Kehoe PG, Hardy J, Mead S, Fox N, Rossor M, Collinge J, Maier W, Jessen F, Schürmann B, Heun R, van den Bussche H, Heuser I, Kornhuber J, Wiltfang J, Dichgans M, Frölich L, Hampel H, Hüll M, Rujescu D, Goate AM, Kauwe JSK, Cruchaga C, Nowotny P, Morris JC, Mayo K, Sleegers K, Bettens K, Engelborghs S, De Deyn PP, Van Broeckhoven C, Livingston G, Bass NJ, Gurling H, McQuillin A, Gwilliam R, Deloukas P, Al-Chalabi A, Shaw CE, Tsolaki M, Singleton AB, Guerreiro R, Mühleisen TW, Nöthen MM, Moebus S, Jöckel K-H, Klopp N, Wichmann H-E, Carrasquillo MM, Pankratz VS, Younkin SG, Holmans PA, O'Donovan M, Owen MJ, Williams J. Genome-wide association study identifies variants at CLU and PICALM associated with Alzheimer's disease. Nat Genet. 2009 Oct;41(10):1088-93.

7. Lambert J-C, Heath S, Even G, Campion D, Sleegers K, Hiltunen M, Combarros O, Zelenika D, Bullido MJ, Tavernier B, Letenneur L, Bettens K, Berr C, Pasquier F, Fiévet N, Barberger-Gateau P, Engelborghs S, De Deyn P, Mateo I, Franck A, Helisalmi S, Porcellini E, Hanon O, European Alzheimer's Disease Initiative Investigators, de Pancorbo MM, Lendon C, Dufouil C, Jaillard C, Leveillard T, Alvarez V, Bosco P, Mancuso M, Panza F, Nacmias B, Bossù P, Piccardi $P$, Annoni G, Seripa $D$, Galimberti D, Hannequin D, Licastro F, Soininen H, Ritchie K, Blanché H, Dartigues J-F, Tzourio C, Gut I, Van Broeckhoven C, Alpérovitch A, Lathrop M, Amouyel P. Genome-wide association study identifies variants at CLU and CR1 associated with Alzheimer's disease. Nat Genet. 2009 Oct;41(10):1094-9.

8. Hollingworth $\mathrm{P}$, Harold D, Sims R, Gerrish A, Lambert J-C, Carrasquillo MM, Abraham R, Hamshere ML, Pahwa JS, Moskvina V, Dowzell K, Jones N, Stretton A, Thomas C, Richards A, Ivanov D, Widdowson C, Chapman J, Lovestone S, Powell J, Proitsi P, Lupton MK, Brayne C, Rubinsztein DC, Gill M, Lawlor B, Lynch A, Brown KS, Passmore PA, Craig D, McGuinness B, Todd S, Holmes C, Mann D, Smith AD, Beaumont H, Warden D, Wilcock G, Love S, Kehoe PG, Hooper NM, Vardy ERLC, Hardy J, Mead S, Fox NC, Rossor M, Collinge J, Maier W, Jessen F, Rüther E, Schürmann B, Heun R, Kölsch H, van den Bussche H, Heuser I, Kornhuber J, Wiltfang J, Dichgans M, Frölich L, Hampel H, Gallacher J, Hüll M, Rujescu D, Giegling I, Goate AM, Kauwe JSK, Cruchaga C, Nowotny P, Morris JC, Mayo K, Sleegers K, Bettens K, Engelborghs S, De Deyn PP, Van Broeckhoven C, Livingston G, Bass NJ, Gurling H, McQuillin A, Gwilliam R, Deloukas P, Al-Chalabi A, Shaw CE, Tsolaki M, Singleton AB, Guerreiro R, Mühleisen TW, Nöthen MM, Moebus S, Jöckel K-H, Klopp N, Wichmann H-E, Pankratz VS, Sando SB, Aasly JO, Barcikowska M, Wszolek ZK,

This article is protected by copyright. All rights reserved. 
Dickson DW, Graff-Radford NR, Petersen RC, Alzheimer's Disease Neuroimaging Initiative, van Duijn CM, Breteler MMB, Ikram MA, DeStefano AL, Fitzpatrick AL, Lopez O, Launer LJ, Seshadri S, CHARGE consortium, Berr C, Campion D, Epelbaum J, Dartigues J-F, Tzourio C, Alpérovitch A, Lathrop M, EADI1 consortium, Feulner TM, Friedrich P, Riehle C, Krawczak M, Schreiber S, Mayhaus M, Nicolhaus S, Wagenpfeil S, Steinberg S, Stefansson H, Stefansson K, Snaedal J, Björnsson S, Jonsson P V, Chouraki V, Genier-Boley B, Hiltunen M, Soininen H, Combarros O, Zelenika D, Delepine M, Bullido MJ, Pasquier F, Mateo I, Frank-Garcia A, Porcellini E, Hanon O, Coto E, Alvarez V, Bosco P, Siciliano G, Mancuso M, Panza F, Solfrizzi V, Nacmias $B$, Sorbi $S$, Bossù $P$, Piccardi $P$, Arosio $B$, Annoni $G$, Seripa $D$, Pilotto $A$, Scarpini E, Galimberti D, Brice A, Hannequin D, Licastro F, Jones L, Holmans PA, Jonsson T, Riemenschneider M, Morgan K, Younkin SG, Owen MJ, O'Donovan M, Amouyel P, Williams J. Common variants at ABCA7, MS4A6A/MS4A4E, EPHA1, CD33 and CD2AP are associated with Alzheimer's disease. Nat Genet. 2011 May;43(5):429-35.

9. Lambert J, Ibrahim-Verbaas C, Harold D, Naj A. Meta-analysis of 74,046 individuals identifies 11 new susceptibility loci for Alzheimer's disease. Nature. 2013;

10. Jun G, Naj AC, Beecham GW, Wang L-S, Buros J, Gallins PJ, Buxbaum JD, ErtekinTaner N, Fallin MD, Friedland R, Inzelberg R, Kramer P, Rogaeva E, St GeorgeHyslop P, Alzheimer's Disease Genetics Consortium, Cantwell LB, Dombroski BA, Saykin AJ, Reiman EM, Bennett DA, Morris JC, Lunetta KL, Martin ER, Montine TJ, Goate AM, Blacker D, Tsuang DW, Beekly D, Cupples LA, Hakonarson H, Kukull W, Foroud TM, Haines J, Mayeux R, Farrer LA, Pericak-Vance MA, Schellenberg GD. Meta-analysis confirms CR1, CLU, and PICALM as alzheimer disease risk loci and reveals interactions with APOE genotypes. Arch Neurol. 2010 Dec;67(12):1473-84.

11. Choi M, Scholl UI, Ji W, Liu T, Tikhonova IR, Zumbo P, Nayir A, Bakkaloğlu A, Ozen S, Sanjad S, Nelson-Williams C, Farhi A, Mane S, Lifton RP. Genetic diagnosis by whole exome capture and massively parallel DNA sequencing. Proc Natl Acad Sci U S A. 2009 Nov 10;106(45):19096-101.

12. Guerreiro R, Wojtas A, Bras J, Carrasquillo M, Rogaeva E, Majounie E, Cruchaga C, Sassi C, Kauwe JSK, Younkin S, Hazrati L, Collinge J, Pocock J, Lashley T, Williams J, Lambert J-C, Amouyel P, Goate A, Rademakers R, Morgan K, Powell J, St. George-Hyslop P, Singleton A, Hardy J. TREM2 Variants in Alzheimer's Disease. N Engl J Med. 2013;368(2):117-27.

13. Tosto G, Reitz C. Genome-wide Association Studies in Alzheimer's Disease: A Review. Curr Neurol Neurosci Rep. 2013 Oct 17;13(10):381.

14. Bras J, Guerreiro R, Darwent L, Parkkinen L, Ansorge O, Escott-Price V, Hernandez DG, Nalls MA, Clark LN, Honig LS, Marder K, Van Der Flier WM, Lemstra A, Scheltens P, Rogaeva E, St George-Hyslop P, Londos E, Zetterberg H, OrtegaCubero S, Pastor P, Ferman TJ, Graff-Radford NR, Ross OA, Barber I, Braae A, Brown K, Morgan K, Maetzler W, Berg D, Troakes C, Al-Sarraj S, Lashley T, Compta Y, Revesz T, Lees A, Cairns N, Halliday GM, Mann D, Pickering-Brown S, Dickson DW, Singleton A, Hardy J. Genetic analysis implicates APOE, SNCA and suggests lysosomal dysfunction in the etiology of dementia with Lewy bodies. Hum Mol Genet. 2014 Dec 1;23(23):6139-46.

15. Samarasekera N, Salman RA-S, Huitinga I, Klioueva N, McLean CA, Kretzschmar H, Smith C, Ironside JW. Brain banking for neurological disorders. Lancet Neurol. 2013 Nov;12(11):1096-105.

This article is protected by copyright. All rights reserved. 
16. Vonsattel JPG, del Amaya MP, Keller CE. Twenty-first century brain banking.

Processing brains for research: The Columbia University methods. Acta Neuropathol. 2008 May 6;115(5):509-32.

17. Kretzschmar H. Brain banking: Opportunities, challenges and meaning for the future. Nat Rev Neurosci. 2009 Jan 3;10(1):70-8.

18. Wray NR, Goddard ME, Visscher PM. Prediction of individual genetic risk of complex disease. Curr Opin Genet Dev. 2008;18(3):257-63.

19. Thal DR, Rüb U, Orantes $M$, Braak $H$. Phases of $A$ beta-deposition in the human brain and its relevance for the development of AD. Neurology. 2002 Jun 25;58(12):1791800.

20. Braak H, Alafuzoff I, Arzberger T, Kretzschmar H, Del Tredici K. Staging of Alzheimer disease-associated neurofibrillary pathology using paraffin sections and immunocytochemistry. Acta Neuropathol. 2006 Oct 12;112(4):389-404.

21. Mirra SS, Heyman A, McKeel D, Sumi SM, Crain BJ, Brownlee LM, Vogel FS, Hughes JP, van Belle G, Berg L. The Consortium to Establish a Registry for Alzheimer's Disease (CERAD). Part II. Standardization of the neuropathologic assessment of Alzheimer's disease. Neurology. 1991 Apr;41(4):479-86.

22. Montine TJ, Phelps CH, Beach TG, Bigio EH, Cairns NJ, Dickson DW, Duyckaerts C, Frosch MP, Masliah E, Mirra SS, Nelson PT, Schneider JA, Thal DR, Trojanowski JQ, Vinters H V., Hyman BT, National Institute on Aging, Alzheimer's Association. National Institute on Aging-Alzheimer's Association guidelines for the neuropathologic assessment of Alzheimer's disease: a practical approach. Acta Neuropathol. 2012 Jan 20;123(1):1-11.

23. McKeith IG, Dickson DW, Lowe J, Emre M, O'Brien JT, Feldman H, Cummings J, Duda JE, Lippa C, Perry EK, Aarsland D, Arai H, Ballard CG, Boeve B, Burn DJ, Costa D, Del Ser T, Dubois B, Galasko D, Gauthier S, Goetz CG, Gomez-Tortosa E, Halliday G, Hansen LA, Hardy J, Iwatsubo T, Kalaria RN, Kaufer D, Kenny RA, Korczyn A, Kosaka K, Lee VMY, Lees A, Litvan I, Londos E, Lopez OL, Minoshima S, Mizuno Y, Molina JA, Mukaetova-Ladinska EB, Pasquier F, Perry RH, Schulz JB, Trojanowski JQ, Yamada M, Consortium on DLB. Diagnosis and management of dementia with Lewy bodies: Third report of the DLB consortium. Neurology. 2005 Dec 27;65(12):1863-72.

24. Mackenzie IRA, Neumann M, Baborie A, Sampathu DM, Du Plessis D, Jaros E, Perry $\mathrm{RH}$, Trojanowski JQ, Mann DMA, Lee VMY. A harmonized classification system for FTLD-TDP pathology. Vol. 122, Acta Neuropathologica. 2011. p. 111-3.

25. Skrobot OA, Attems J, Esiri M, Hortobágyi T, Ironside JW, Kalaria RN, King A, Lammie GA, Mann D, Neal J, Ben-Shlomo Y, Kehoe PG, Love S. Vascular cognitive impairment neuropathology guidelines (VCING): the contribution of cerebrovascular pathology to cognitive impairment. Brain. 2016 Nov 2;139(11):2957-69.

26. Smallwood A, Oulhaj A, Joachim C, Christie S, Sloan C, Smith AD, Esiri M. Cerebral subcortical small vessel disease and its relation to cognition in elderly subjects: a pathological study in the Oxford Project to Investigate Memory and Ageing (OPTIMA) cohort. Neuropathol Appl Neurobiol. 2012 Jun;38(4):337-43.

27. Grinberg LT, Thal DR. Vascular pathology in the aged human brain. Acta

This article is protected by copyright. All rights reserved. 
Neuropathol. 2010 Mar 14;119(3):277-90.

28. Costello H, Hayes GM, Highton-Williamson E, Nurock S, Hanbury D, Francis PT. A pilot study of potential brain donor satisfaction and attitudes towards telephone assessment. Int J Geriatr Psychiatry. 2016;

29. Li H, Durbin R. Fast and accurate long-read alignment with Burrows-Wheeler transform. Bioinformatics. 2010 Mar 1;26(5):589-95.

30. McKenna A, Hanna M, Banks E, Sivachenko A, Cibulskis K, Kernytsky A, Garimella K, Altshuler D, Gabriel S, Daly M, DePristo MA. The Genome Analysis Toolkit: a MapReduce framework for analyzing next-generation DNA sequencing data. Genome Res. 2010 Sep 1;20(9):1297-303.

31. Wang K, Li M, Hakonarson $\mathrm{H}$. ANNOVAR: functional annotation of genetic variants from high-throughput sequencing data. Nucleic Acids Res. 2010 Sep 1;38(16):e164e164.

32. McLaren W, Gil L, Hunt SE, Riat HS, Ritchie GRS, Thormann A, Flicek P, Cunningham F. The Ensembl Variant Effect Predictor. bioRxiv. 2016;42374.

33. Danecek P, Auton A, Abecasis G, Albers CA, Banks E, DePristo MA, Handsaker RE, Lunter G, Marth GT, Sherry ST, McVean G, Durbin R. The variant call format and VCFtools. Bioinformatics. 2011 Aug 1;27(15):2156-8.

34. Cingolani P, Platts A, Wang LLL, Coon M, Nguyen T, Wang LLL, Land SJ, Lu X, Ruden DM. A program for annotating and predicting the effects of single nucleotide polymorphisms, SnpEff. Fly (Austin). 2012 Apr 27;6(2):80-92.

35. Thorvaldsdottir H, Robinson JT, Mesirov JP. Integrative Genomics Viewer (IGV): highperformance genomics data visualization and exploration. Brief Bioinform. $2013 \mathrm{Mar}$ $1 ; 14(2): 178-92$.

36. Cruts M, Theuns J, Van Broeckhoven C. Locus-specific mutation databases for neurodegenerative brain diseases. Hum Mutat. 2012 Sep 1;33(9):1340-4.

37. Purcell S. A whole-genome association toolset. 2008;

38. Lee S, Miropolsky L, Wu M. SKAT: SNP-set (Sequence) kernel association test. 082, UR L http//CRAN R-project org/package= SKAT. 2013;

39. Euesden J, Lewis C, O'Reilly P. PRSice: polygenic risk score software. Bioinformatics. 2014;

40. Karch CM, Ezerskiy LA, Bertelsen S, Goate AM, Albert MS, Albin RL, Apostolova LG, Arnold SE, Baldwin CT, Barber R, Barmada MM, Barnes LL, Beach TG, Beecham GW, Beekly D, Bennett DA, Bigio EH, Bird TD, Blacker D, Boeve BF, Bowen JD, Boxer A, Burke JR, Buxbaum JD, Cairns NJ, Cantwell LB, Cao C, Carlson CS, Carney RM, Carrasquillo MM, Carroll SL, Chui HC, Clark DG, Corneveaux J, Crane PK, Cribbs DH, Crocco EA, Cruchaga C, De Jager PL, DeCarli C, DeKosky ST, Demirci FY, Dick M, Dickson DW, Duara R, Ertekin-Taner N, Evans D, Faber KM, Fallon KB, Farlow MR, Ferris S, Foroud TM, Frosch MP, Galasko DR, Ganguli M, Gearing M, Geschwind DH, Ghetti B, Gilbert JR, Gilman S, Glass JD, Graff-Radford NR, Green RC, Growdon JH, Hakonarson H, Hamilton-Nelson KL, Hamilton RL, Hardy J, Harrell LE, Head E, Honig LS, Huentelman MJ, Hulette CM, Hyman BT,

This article is protected by copyright. All rights reserved. 
Jarvik GP, Jicha GA, Jin LW, Kamboh MI, Karydas A, Kauwe JSK, Kaye JA, Kim R, Koo EH, Kowall NW, Kramer JH, Kramer P, Kukull WA, LaFerla FM, Lah JJ, Larson EB, Leverenz JB, Levey AI, Li G, Lin CF, Lieberman AP, Lopez OL, Lunetta KL, Lyketsos CG, Mack WJ, Marson DC, Martin ER, Martiniuk F, Mash DC, Masliah E, McCormick WC, McCurry SM, McDavid AN, McKee AC, Mesulam M, Miller BL, Miller CA, Miller JW, Montine TJ, Morris JC, Murrell JR, Myers AJ, Naj AC, Olichney JM, Pankratz VS, Parisi JE, Peskind E, Petersen RC, Pierce A, Poon WW, Potter H, Quinn JF, Raj A, Rajbhandary RA, Raskind M, Reiman EM, Reisberg B, Reitz C, Ringman JM, Roberson ED, Rogaeva E, Rosen HJ, Rosenberg RN, Sano M, Saykin AJ, Schneider JA, Schneider LS, Seeley WW, Smith AG, Sonnen JA, Spina S, Stern RA, Tanzi RE, Trojanowski JQ, Troncoso JC, Tsuang DW, Valladares O, Van Deerlin VM, Van Eldik LJ, Vardarajan BN, Vinters H V., Vonsattel JP, Weintraub S, WelshBohmer KA, Williamson J, Woltjer RL, Wright CB, Younkin SG, Yu CE, Yu L. Alzheimer's disease risk polymorphisms regulate gene expression in the ZCWPW1 and the CELF1 loci. PLoS One. 2016;11(2):1-22.

41. Allen M, Kachadoorian M, Carrasquillo MMM, Karhade A, Manly L, Burgess JD, Wang C, Serie D, Wang X, Siuda J, Zou F, Chai HS, Younkin C, Crook J, Medway C, Nguyen T, Ma L, Malphrus K, Lincoln S, Petersen RC, Graff-Radford NR, Asmann YW, Dickson DW, Younkin SG, Ertekin-Taner N. Late-onset Alzheimer disease risk variants mark brain regulatory loci. Neurol Genet. 2015;1(2):e15.

42. Dempster E, Burcescu I, Wigg K, Kiss E. Evidence of an association between the vasopressin V1b receptor gene (AVPR1B) and childhood-onset mood disorders. Arch Gen. 2007;

43. Becker-Pauly $C$, Pietrzik $C$. The Metalloprotease meprin $\beta$ is an alternative $\beta$ secretase of APP. Front Mol Neurosci. 2016;

44. Schönherr C, Bien J, Isbert S. Generation of aggregation prone N-terminally truncated amyloid $\beta$ peptides by meprin $\beta$ depends on the sequence specificity at the cleavage site. Molecular. 2016;

45. Escott-Price V, Shoai M, Pither R, Williams J, Hardy J. Polygenic score prediction captures nearly all common genetic risk for Alzheimer's disease. Neurobiol Aging. 2017;49:214.

46. Cookson MR, Lockhart PJ, McLendon C, O'Farrell C, Schlossmacher M, Farrer MJ. RING finger 1 mutations in Parkin produce altered localization of the protein. Hum Mol Genet. 2003 Sep 18;12(22):2957-65.

47. TREM2 and Neurodegenerative Disease. N Engl J Med. 2013 Oct 17;369(16):156470.

48. Sassi C, Nalls MA, Ridge PG, Gibbs JR, Ding J, Lupton MK, Troakes C, Lunnon K, Al-Sarraj S, Brown KS, Medway C, Clement N, Lord J, Turton J, Bras J, Almeida MR, Passmore P, Craig D, Johnston J, McGuinness B, Todd S, Heun R, Kölsch H, Kehoe PG, Vardy ERLC, Hooper NM, Mann DM, Pickering-Brown S, Brown K, Lowe J, Morgan K, Smith AD, Wilcock G, Warden D, Holmes C, Holstege H, Louwersheimer E, van der Flier WM, Scheltens P, Van Swieten JC, Santana I, Oliveira C, Morgan K, Powell JF, Kauwe JS, Cruchaga C, Goate AM, Singleton AB, Guerreiro R, Hardy J. ABCA7 p.G215S as potential protective factor for Alzheimer's disease. Neurobiol Aging. 2016;46:235.e1-235.e9.

49. De Roeck A, Van den Bossche T, van der Zee J, Verheijen J, De Coster W, Van

This article is protected by copyright. All rights reserved. 
Dongen J, Dillen L, Baradaran-Heravi Y, Heeman B, Sanchez-Valle R, Lladó A, Nacmias B, Sorbi S, Gelpi E, Grau-Rivera O, Gómez-Tortosa E, Pastor P, OrtegaCubero S, Pastor MA, Graff C, Thonberg H, Benussi L, Ghidoni R, Binetti G, de Mendonça A, Martins M, Borroni B, Padovani A, Almeida MR, Santana I, DiehlSchmid J, Alexopoulos P, Clarimon J, Lleó A, Fortea J, Tsolaki M, Koutroumani M, Matěj R, Rohan Z, De Deyn P, Engelborghs S, Cras P, Van Broeckhoven C, Sleegers K, Bessi V, Bagnoli S, do Couto FS, Verdelho A, Fratiglioni L, Padovani A, Rohan Z, Razquin C, Lorenzo E, Iglesias E, Seijo-Martínez M, Rene R, Gascon J, Campdelacreu J, Blesa R. Deleterious ABCA7 mutations and transcript rescue mechanisms in early onset Alzheimer's disease. Acta Neuropathol. 2017 Apr $27 ; 134(3): 475-87$.

50. Ross OOA, Soto-Ortolaza AAI, Heckman MMG, Aasly JOJ, Abahuni N, Annesi G, Bacon JA, Bardien S, Bozi M, Brice A, Brighina L, Van Broeckhoven C, Carr J, Chartier-Harlin M-C, Dardiotis E, Dickson DW, Diehl NN, Elbaz A, Ferrarese C, Ferraris A, Fiske B, Gibson JM, Gibson R, Hadjigeorgiou GM, Hattori N, Ioannidis JP, Jasinska-Myga B, Jeon BS, Kim YJ, Klein C, Kruger R, Kyratzi E, Lesage S, Lin C-H, Lynch T, Maraganore DM, Mellick GD, Mutez E, Nilsson C, Opala G, Park SS, Puschmann A, Quattrone A, Sharma M, Silburn PA, Sohn YH, Stefanis L, Tadic V, Theuns J, Tomiyama H, Uitti RJ, Valente EM, van de Loo S, Vassilatis DK, VilariñoGüell C, White LR, Wirdefeldt K, Wszolek ZK, Wu R-M, Farrer MJ. Association of LRRK2 exonic variants with susceptibility to Parkinson's disease: a case-control study. 2011 Oct;10(10):898-908.

51. Zhao Y, Ho P, Yih Y, Chen C, Lee WWL, Tan EEK. LRRK2 variant associated with Alzheimer's disease. 2011 Nov;32(11):1990-3.

This article is protected by copyright. All rights reserved. 
Table 1. Demographics of LOAD cases and cognitively normal samples in the BDR cohort. The cohort contains individuals from multiple centres. Sample demographics are divided into (a) LOAD cases and (b) cognitively normal controls for each centre and overall. Information provided includes: Number and percentage of case or control individuals per centre [N (\%)], Mean age at death with standard deviation [Mean AAD $( \pm$ SD)], Number and percentage of case or control females per centre [Females (\%)], Number and percentages of case or control individuals harbouring at least one APOE $\varepsilon 4$ allele [APOE $\varepsilon 4+$ $(\%)], A P O E \varepsilon 4$ minor allele frequency [APOE $\varepsilon 4 \mathrm{MAF}$ ], Number and percentage of case or control individuals with two $\varepsilon 4$ alleles [APOE $\varepsilon 4 \varepsilon 4$ (\%)].

\begin{tabular}{|c|c|c|c|c|c|c|}
\hline Centre & N (\%) & $\begin{array}{c}\text { Mean AAD } \\
( \pm \text { SD })\end{array}$ & $\begin{array}{c}\text { Females } \\
(\%)\end{array}$ & $\begin{array}{c}\text { APOE \&4+ } \\
(\%)\end{array}$ & $\begin{array}{c}\text { APOE } \varepsilon 4 \\
\text { MAF }\end{array}$ & $\begin{array}{c}\text { APOE } \varepsilon 4 \varepsilon 4 \\
\text { (\%) }\end{array}$ \\
\hline Bristol & $7(41.2)$ & $86.0( \pm 6.1)$ & $4(57.1)$ & $7(100.0)$ & 0.43 & $1(14.3)$ \\
\hline London & $29(58.0)$ & $82.0( \pm 7.4)$ & $18(62.1)$ & 17 (58.6) & 0.35 & $4(13.8)$ \\
\hline Manchester & 27 (81.8) & $80.8( \pm 8.2)$ & $12(44.4)$ & $18(66.7)$ & 0.46 & 7 (25.9) \\
\hline Newcastle & 15 (78.9) & $85.1( \pm 8.3)$ & 8 (53.3) & $10(66.7)$ & 0.39 & $2(13.3)$ \\
\hline Oxford & $54(81.8)$ & $83.1( \pm 8.9)$ & $28(51.9)$ & $33(61.1)$ & 0.4 & $9(16.6)$ \\
\hline All & $132(71.4)$ & $82.5( \pm 8.4)$ & $70(53.0)$ & 85 (64.4) & 0.4 & $23(17.3)$ \\
\hline
\end{tabular}

(a) Late-onset Alzheimer's disease cases.

This article is protected by copyright. All rights reserved. 


\begin{tabular}{|c|c|c|c|c|c|c|}
\hline Centre & N (\%) & $\begin{array}{c}\text { Mean AAD } \\
( \pm \text { SD })\end{array}$ & $\begin{array}{c}\text { Females } \\
(\%)\end{array}$ & $\begin{array}{c}\text { APOE ₹4+ } \\
(\%)\end{array}$ & $\begin{array}{c}A P O E \varepsilon 4 \\
\text { MAF }\end{array}$ & $\begin{array}{c}A P O E \varepsilon 4 \varepsilon 4 \\
(\%)\end{array}$ \\
\hline Bristol & $10(58.8)$ & $84.5( \pm 7.5)$ & $4(40.0)$ & $6(60.0)$ & 0.15 & $0(0.0)$ \\
\hline London & $21(42.0)$ & $83.0( \pm 0.0)$ & $11(52.4)$ & $5(23.8)$ & 0.12 & $0(0.0)$ \\
\hline Manchester & $6(18.2)$ & $87.8( \pm 5.0)$ & $4(66.7)$ & $0(0.0)$ & 0 & $0(0.0)$ \\
\hline Newcastle & $4(21.1)$ & $86.3( \pm 4.6)$ & $1(25.0)$ & $1(25.0)$ & 0.13 & $0(0.0)$ \\
\hline Oxford & $12(18.2)$ & $86.4( \pm 7.8)$ & 7 (58.3) & $1(8.3)$ & 0.04 & $0(0.0)$ \\
\hline All & $53(28.6)$ & $85.9( \pm 6.5)$ & $27(50.9)$ & $13(24.5)$ & 0.09 & $0(0.0)$ \\
\hline
\end{tabular}

(b) Cognitively normal control samples.

This article is protected by copyright. All rights reserved. 
Table 2. Burden analysis results for exome-wide analysis. Burden analysis of all genes was performed using a C-alpha test without correction for covariates. The results shown are significant to $\mathrm{P}<0.001$. Information includes: Gene name [Gene], mRNA [mRNA ID], chromosomal position in genome build hg19 [Position], number of variants contributing to the signal [Number of Variants], significance [P-value].

\begin{tabular}{lllcl}
\hline \multicolumn{1}{c}{ Gene } & \multicolumn{1}{c}{ mRNA ID } & \multicolumn{1}{c}{ Position } & $\begin{array}{c}\text { Number of } \\
\text { Variants }\end{array}$ & P-value \\
\hline PILRA & NM_013439 & $7: 99971313-99997454$ & 5 & $3.40 \mathrm{E}-05$ \\
PRSS45 & NM_199183 & $3: 46783959-46785453$ & 4 & $5.92 \mathrm{E}-05$ \\
THNSL2 & NM_001244676 & $2: 88470874-88485392$ & 12 & $1.49 \mathrm{E}-04$ \\
KLK2 & NM_001002231 & $19: 51376837-51381777$ & 8 & $1.96 \mathrm{E}-04$ \\
STOX2 & NM_020225 & $4: 184930646-184932631$ & 8 & $2.42 \mathrm{E}-04$ \\
SEC31A & NM_001077206 & $4: 83740163-83803115$ & 23 & $3.58 \mathrm{E}-04$ \\
PRSS42 & NM_182702 & $3: 46875258-46875258$ & 1 & $3.81 \mathrm{E}-04$ \\
HAS3 & NM_138612 & $16: 69143481-69152391$ & 4 & $4.09 \mathrm{E}-04$ \\
KLRF2 & NM_001190765 & $12: 10041364-10048327$ & 5 & $5.08 \mathrm{E}-04$ \\
SLC22A2 & NM_003058 & $6: 160638357-160677614$ & 9 & $5.48 \mathrm{E}-04$ \\
GRIK2 & NM_001166247 & $6: 102134022-102516260$ & 10 & $5.77 \mathrm{E}-04$ \\
TRDMT1 & NM_004412 & $10: 17194026-17243638$ & 12 & $6.86 \mathrm{E}-04$ \\
FAM136A & NM_032822 & $2: 70528601-70529205$ & 5 & $7.25 \mathrm{E}-04$ \\
ITGAL & NM_001114380 & $16: 30484308-30522152$ & 13 & $7.82 \mathrm{E}-04$ \\
\hline
\end{tabular}

This article is protected by copyright. All rights reserved. 


\begin{tabular}{lllll}
\hline APOC1 & NM_001645 & $19: 45419414-45422561$ & 2 & $8.28 \mathrm{E}-04$ \\
HAS3 & NM_001199280 & $16: 69143481-69143816$ & 3 & $8.52 \mathrm{E}-04$ \\
TMIE & NM_147196 & $3: 46742941-46751229$ & 3 & $8.84 \mathrm{E}-04$ \\
BCR & NM_004327 & $22: 23523602-23657604$ & 24 & $8.96 \mathrm{E}-04$ \\
POU4F2 & NM_004575 & $4: 147560411-147561971$ & 6 & $9.54 \mathrm{E}-04$ \\
\hline
\end{tabular}

This article is protected by copyright. All rights reserved. 
Table 3. Top results shown for exome-wide association analysis of non-singleton variants. Logistic regression results are shown for variants associated with $\mathrm{AD}(\mathrm{P}<0.001)$. Significance values were adjusted for the covariates sex, age at death and number of $A P O E \varepsilon 4$ alleles. Information includes: Gene containing the variant [Gene], Variant RSID [Variant], Position in hg19 [Position], allelic change [Allele], MAF in ExAC database [ExAC MAF], MAF and counts in cases and controls [MAF (Count)], Significance of association [P-value], Size of effect with 95\% confidence intervals [Odds Ration (95\% Cl)], coding consequence [Consequence], amino acid change in protein [Protein Change], predicted consequence of change using SIFT and Polyphen2 [Functional Prediction]. * indicates discrepancy between SIFT and Polyphen2 predictions.

\begin{tabular}{|c|c|c|c|c|c|c|c|c|c|c|c|}
\hline \multirow{2}{*}{ Gene } & \multirow{2}{*}{ Variant } & \multirow{2}{*}{ Position } & \multirow{2}{*}{ Allele } & \multirow{2}{*}{$\begin{array}{l}\text { EXAC } \\
\text { MAF }\end{array}$} & \multicolumn{2}{|c|}{ MAF (Count) } & \multirow{2}{*}{ P-value } & \multirow{2}{*}{$\begin{array}{l}\text { Odds Ratio }(95 \% \\
\text { Cl) }\end{array}$} & \multirow{2}{*}{ Consequence } & \multirow{2}{*}{$\begin{array}{l}\text { Protein } \\
\text { Change }\end{array}$} & \multirow{2}{*}{$\begin{array}{l}\text { Functional } \\
\text { Prediction }\end{array}$} \\
\hline & & & & & Case & Control & & & & & \\
\hline TCEB3 & rs2235541 & $1: 24077451$ & $C>T$ & 0.09 & $0.06(15)$ & $0.15(16)$ & $2.44 \mathrm{E}-04$ & $0.15(0.06-0.42)$ & Missense & T145M & Deleterious * \\
\hline$A V P R 1 B$ & rs35369693 & $1: 206224635$ & $\mathrm{G}>\mathrm{C}$ & 0.04 & $0.05(13)$ & $0.16(17)$ & 8.44E-04 & $0.21(0.09-0.53)$ & Missense & K65N & $\begin{array}{l}\text { Probably } \\
\text { damaging }\end{array}$ \\
\hline PRSS45 & rs58830807 & $3: 46783959$ & $\mathrm{~T}>\mathrm{C}$ & 0.18 & $0.09(23)$ & $0.24(25)$ & 1.41E-04 & $0.21(0.1-0.47)$ & Missense & I190V & Tolerated \\
\hline PRSS45 & rs58943210 & $3: 46784467$ & $\mathrm{G}>\mathrm{A}$ & 0.18 & $0.09(23)$ & $0.23(24)$ & $2.67 \mathrm{E}-04$ & $0.23(0.1-0.5)$ & Missense & P130L & Tolerated \\
\hline SEC31A & rs 10025654 & 4:83795806 & $C>T$ & 0.51 & $0.4(105)$ & $0.58(62)$ & $5.29 \mathrm{E}-04$ & $0.38(0.22-0.66)$ & Synonymous & R199 & $\begin{array}{l}\text { No functional } \\
\text { change }\end{array}$ \\
\hline ITPR3 & rs35506178 & $6: 33658780$ & $C>T$ & 0.04 & $0.03(7)$ & $0.08(9)$ & 8.50E-04 & $0.12(0.03-0.41)$ & Synonymous & A2373 & $\begin{array}{l}\text { No functiona } \\
\text { change }\end{array}$ \\
\hline PCLO & rs2877 & $7: 82764425$ & $\mathrm{G}>\mathrm{C}$ & 0.75 & $0.26(69)$ & $0.44(47)$ & 4.88E-04 & $0.36(0.2-0.64)$ & Missense & S814T & Benign \\
\hline CPA1 & rs968404 & 7:130022041 & $C>T$ & 0.13 & $0.14(38)$ & $0.25(26)$ & 4.67E-04 & $0.26(0.12-0.55)$ & Synonymous & Y158 & $\begin{array}{l}\text { No functiona } \\
\text { change }\end{array}$ \\
\hline CWF19L2 & rs659040 & 11:107299631 & $\mathrm{G}>\mathrm{A}$ & 0.16 & $0.15(40)$ & $0.32(34)$ & $2.28 \mathrm{E}-04$ & $0.27(0.13-0.54)$ & Missense & $\mathrm{H} 443 \mathrm{Y}$ & Tolerated \\
\hline
\end{tabular}

This article is protected by copyright. All rights reserved. 


\begin{tabular}{|c|c|c|c|c|c|c|c|c|c|c|c|}
\hline NTN4 & rs17851048 & 12:96077312 & $C>T$ & 0.22 & $0.2(53)$ & $0.41(43)$ & $2.18 \mathrm{E}-04$ & $0.31(0.17-0.58)$ & Synonymous & A452 & $\begin{array}{l}\text { No functional } \\
\text { change }\end{array}$ \\
\hline TMEM260 & rs17776256 & 14:57075920 & $G>T$ & 0.12 & $0.08(20)$ & $0.18(19)$ & 4.96E-04 & $0.21(0.09-0.5)$ & Missense & A245S/T & $\begin{array}{l}\text { Probably } \\
\text { damaging }\end{array}$ \\
\hline UBR7 & rs2286653 & 14:93673655 & $G>A$ & 0.15 & $0.05(12)$ & $0.16(17)$ & $6.21 \mathrm{E}-04$ & $0.17(0.06-0.47)$ & Missense & A7T & Tolerated \\
\hline IGFALS & rs17559 & $16: 1841033$ & $G>A$ & 0.15 & $0.07(18)$ & $0.2(21)$ & 8.34E-04 & $0.26(0.12-0.57)$ & Synonymous & Y500 & $\begin{array}{l}\text { No functional } \\
\text { change }\end{array}$ \\
\hline MEP1B & rs173032 & 18:29795076 & $C>T$ & 0.68 & $0.41(107)$ & $0.25(27)$ & $6.48 \mathrm{E}-04$ & $3.08(1.61-5.89)$ & Synonymous & S537 & $\begin{array}{l}\text { No functional } \\
\text { change }\end{array}$ \\
\hline LRRC8E & rs2042919 & 19:7963949 & $A>G$ & 0.23 & $0.25(67)$ & $0.36(38)$ & $6.45 E-04$ & $0.32(0.17-0.62)$ & Missense & E181G & Tolerated \\
\hline LRRC8E & rs3745382 & 19:7964727 & $G>A$ & 0.21 & $0.26(68)$ & $0.36(38)$ & $6.60 \mathrm{E}-04$ & $0.32(0.17-0.62)$ & Synonymous & E440 & $\begin{array}{l}\text { No functional } \\
\text { change }\end{array}$ \\
\hline FPR1 & rs5030878 & 19:52250216 & $\mathrm{G}>\mathrm{A}$ & 0.81 & $0.19(50)$ & $0.35(37)$ & $4.46 \mathrm{E}-04$ & $0.32(0.17-0.61)$ & Missense & I11T & Tolerated \\
\hline
\end{tabular}

This article is protected by copyright. All rights reserved. 
Table 4. Predictive accuracy model for 132 AD cases versus 53 controls. Different predictors were compared for their accuracy in predicting risk of developing AD. APOE $\varepsilon 4$ and $\varepsilon 2$ alleles, sex, age at death and genotypes for 19 of the GWAS SNPs were used as predictors. PRS were constructed using independent variants associated with $A D$ at a threshold of $P<0.05$, excluding the $A P O E$ region $\pm 500 \mathrm{~kb}$ and the GWAS variants. Nagelkerke's $R^{2}$ expresses the proportion of variance explained by the model, with the largest $R^{2}$ value indicating the best model. Area under the Receiver Operating Characteristic curve (AUC) is a measure of predictive accuracy, which quantifies the overall ability to discriminate between case and control individuals. The Hosmer-Lemeshow statistic is a goodness of fit test for risk prediction models, with a significant result indicating that the data is a poor fit to the model.

\begin{tabular}{|c|c|c|c|c|}
\hline Model & Nagelkerke's $\mathbf{R}^{2}$ & $\begin{array}{l}\text { Area under ROC } \\
\text { curve (AUC) }\end{array}$ & AUC $95 \% \mathrm{Cl}$ & $\begin{array}{c}\text { Hosmer-Lemeshow } \\
\text { Test P-value }\end{array}$ \\
\hline$\varepsilon 4$ & 0.086 & 0.718 & $0.642-0.794$ & 0.001 \\
\hline$\varepsilon 4+\varepsilon 2$ & 0.215 & 0.734 & $0.660-0.809$ & 0.347 \\
\hline$\varepsilon 4+\varepsilon 2+\operatorname{Sex}+A g e$ & 0.223 & 0.742 & $0.668-0.816$ & 0.891 \\
\hline$\varepsilon 4+\varepsilon 2+\operatorname{Sex}+A g e+G W A S$ & 0.366 & 0.830 & $0.770-0.891$ & 0.816 \\
\hline$\varepsilon 4+\varepsilon 2+\operatorname{Sex}+$ Age + GWAS + PRS $(P<0.05)$ & 0.378 & 0.838 & $0.779-0.898$ & 0.536 \\
\hline
\end{tabular}

This article is protected by copyright. All rights reserved. 
Table 5. Coding variants found in familial AD genes APP, PSEN1 and PSEN2 in LOAD cohort. Coding variants present in BDR samples in familial AD genes APP (1), PSEN1 (1) and PSEN2 (4) are catalogued here with a prediction of the functional consequences of each mutation. * indicates discrepancy between SIFT and Polyphen2 predictions.

\begin{tabular}{|c|c|c|c|c|c|c|c|c|c|}
\hline \multirow{2}{*}{ Gene } & \multirow{2}{*}{ SNP } & \multirow{2}{*}{ Position } & \multirow{2}{*}{ Allele } & \multirow{2}{*}{$\begin{array}{l}\text { ExAC } \\
\text { MAF }\end{array}$} & \multicolumn{2}{|c|}{ MAF (Counts) } & \multirow{2}{*}{ Consequence } & \multirow{2}{*}{$\begin{array}{l}\text { Protein } \\
\text { Change }\end{array}$} & \multirow{2}{*}{ Functional Prediction } \\
\hline & & & & & Case & Control & & & \\
\hline$A P P$ & rs148888161 & $21: 27264121$ & $\mathrm{G}>\mathrm{A}$ & 0.002 & $0.007(2)$ & $0.009(1)$ & Synonymous & G708 & No functional change \\
\hline PSEN1 & rs17125721 & $14: 73673178$ & $A>G$ & 0.015 & $0.015(5)$ & $0.009(1)$ & Missense & E318G & Probably damaging * \\
\hline \multirow{4}{*}{ PSEN2 } & rs11405 & $1: 227069677$ & $\mathrm{C}>\mathrm{T}$ & 0.76 & $0.189(50)$ & $0.198(21)$ & Synonymous & A23 & No functional change \\
\hline & rs1046240 & $1: 227071525$ & $\mathrm{~T}>\mathrm{C}$ & 0.49 & $0.439(116)$ & $0.396(42)$ & Synonymous & H87 & No functional change \\
\hline & rs63750197 & $1: 227073271$ & $C>T$ & 0.0006 & $0.004(1)$ & $0.009(1)$ & Missense & S130L & Possibly damaging * \\
\hline & rs61730652 & $1: 227076671$ & $\mathrm{~T}>\mathrm{C}$ & 0.013 & $0.004(1)$ & $0(0)$ & Synonymous & S236 & No functional change \\
\hline
\end{tabular}

This article is protected by copyright. All rights reserved. 
Table 6. Cataloguing pathogenic mutations in other familial neurologic genes. Variants in genes previously linked to other neurologic disorders were investigated for known pathogenic mutations. Only mutations causing an amino acid change are listed here therefore synonymous mutations were excluded. Clinical significance was determined from information available online from AD\&FTD and PD mutation databases. 'NA' indicates that no functional or clinical information or MAF was available. * indicates discrepancy between SIFT and Polyphen2 predictions.

\begin{tabular}{|c|c|c|c|c|c|c|c|c|c|c|}
\hline \multirow{2}{*}{ Gene } & \multirow{2}{*}{ SNP } & \multirow{2}{*}{ Position } & \multirow{2}{*}{ Allele } & \multirow{2}{*}{$\begin{array}{l}\text { ExAC } \\
\text { MAF }\end{array}$} & \multicolumn{2}{|c|}{ MAF (Counts) } & \multirow{2}{*}{ Consequence } & \multirow{2}{*}{$\begin{array}{l}\text { Protein } \\
\text { Change }\end{array}$} & \multirow{2}{*}{$\begin{array}{l}\text { Functional } \\
\text { Prediction }\end{array}$} & \multirow{2}{*}{$\begin{array}{c}\text { Clinical } \\
\text { Significance }\end{array}$} \\
\hline & & & & & Case & Control & & & & \\
\hline$C H M P 2 B$ & chr3:87299112 & $3: 87299112$ & ATGAC $>A$ & $\mathrm{NA}$ & $0.003(1)$ & $0.009(1)$ & Frameshift & $\overline{N A}$ & $\mathrm{NA}$ & $\mathrm{NA}$ \\
\hline LRRK2 & rs7308720 & $12: 40657700$ & $\mathrm{C}>\mathrm{G}$ & 0.086 & $0.078(24)$ & $0.046(5)$ & Missense & N551K & $\begin{array}{l}\text { Probably } \\
\text { damaging }\end{array}$ & $\begin{array}{l}\text { Not } \\
\text { pathogenic }\end{array}$ \\
\hline LRRK2 & rs33958906 & 12:40707861 & $C>T$ & 0.030 & $0.026(8)$ & $0.018(2)$ & Missense & P1542S & $\begin{array}{l}\text { Probably } \\
\text { damaging }\end{array}$ & $\begin{array}{l}\text { Not } \\
\text { pathogenic }\end{array}$ \\
\hline LRRK2 & chr12:40697972 & 12:40697972 & $A>T$ & NA & $0.003(1)$ & $0.009(1)$ & Missense & L1271P & NA & NA \\
\hline PARK2 & rs149953814 & 6:161771219 & $\mathrm{G}>\mathrm{A}$ & 0.001 & $0.003(1)$ & $0.009(1)$ & Missense & P246L & $\begin{array}{l}\text { Probably } \\
\text { damaging }\end{array}$ & $\begin{array}{l}\text { Pathogenic } \\
\text { nature } \\
\text { unclear }\end{array}$ \\
\hline PARK2 & rs34424986 & 6:162206852 & $\mathrm{G}>\mathrm{A}$ & 0.002 & $0.003(1)$ & $0.009(1)$ & Missense & $\begin{array}{c}\mathrm{R} 84 \mathrm{~W} / \mathrm{R} \\
275 \mathrm{~T}\end{array}$ & $\begin{array}{l}\text { Probably } \\
\text { damaging }\end{array}$ & Pathogenic \\
\hline PINK1 & rs148871409 & $1: 20960385$ & $A>T$ & 0.064 & $0.059(18)$ & $0.045(5)$ & Missense & Q115P & $\begin{array}{l}\text { Probably } \\
\text { damaging * }\end{array}$ & NA \\
\hline PINK1 & rs1043424 & $1: 20977000$ & $A>C$ & 0.297 & $0.311(95)$ & $0.255(28)$ & Missense & N521T & Tolerated & $\begin{array}{l}\text { Not } \\
\text { pathogenic }\end{array}$ \\
\hline$P R N P$ & rs138688873 & 20:4680095 & $\begin{array}{l}\text { 229- } \\
\text { 252del24 }\end{array}$ & 0.019 & $0.003(1)$ & $0.009(1)$ & $\begin{array}{l}\text { In-frame } \\
\text { deletion }\end{array}$ & 77-84del & NA & NA \\
\hline PRNP & rs1799990 & $20: 4680251$ & $A>G$ & 0.308 & $0.343(105)$ & $0.382(42)$ & Missense & M129V & Tolerated & $\begin{array}{l}\text { Risk factor, } \\
\text { likely benign }\end{array}$ \\
\hline
\end{tabular}

This article is protected by copyright. All rights reserved. 
Table 7. Single-SNP association results for variants in known neurological genes with AD. Association results for single variants with Alzheimer's disease, corrected for sex, age at death and $A P O E \varepsilon 4$ allele count. The variants significant to $\mathrm{P}<0.05$ are listed here with predicted functional consequence. * indicates discrepancy between SIFT and Polyphen2 predictions.

\begin{tabular}{|c|c|c|c|c|c|c|c|c|c|c|c|}
\hline \multirow{2}{*}{ Gene } & \multirow{2}{*}{ SNP } & \multirow{2}{*}{ Position } & \multirow{2}{*}{ Allele } & \multirow{2}{*}{$\begin{array}{l}\text { ExAC } \\
\text { MAF }\end{array}$} & \multicolumn{2}{|c|}{ MAF (Count) } & \multirow{2}{*}{ P-value } & \multirow{2}{*}{$\begin{array}{l}\text { Odds Ratio } \\
\text { (95\% Cl) }\end{array}$} & \multirow{2}{*}{ Consequence } & \multirow{2}{*}{$\begin{array}{l}\text { Protein } \\
\text { Change }\end{array}$} & \multirow{2}{*}{$\begin{array}{l}\text { Functional } \\
\text { Prediction }\end{array}$} \\
\hline & & & & & Case & Control & & & & & \\
\hline LRRK2 & rs35303786 & $12: 40713899$ & $\mathrm{~T}>\mathrm{C}$ & 0.01 & $0.01(3)$ & $0.05(5)$ & 0.018 & $0.14(0.03-0.71)$ & Missense & M1646T & Tolerated \\
\hline SLC24A4 & rs7144273 & 14:92920371 & $\mathrm{T}>\mathrm{C}$ & 0.50 & $0.5(153)$ & $0.39(43)$ & 0.044 & $1.63(1.01-2.63)$ & Synonymous & P319 & $\begin{array}{l}\text { No } \\
\text { functional } \\
\text { change }\end{array}$ \\
\hline$A B C A 7$ & rs3764645 & 19:1042809 & $A>G$ & 0.48 & $0.42(127)$ & $0.6(66)$ & 0.001 & $0.43(0.26-0.72)$ & Missense & E188G & Tolerated \\
\hline$A B C A 7$ & rs3752234 & 19:1047002 & $\mathrm{G}>\mathrm{A}$ & 0.55 & $0.51(157)$ & $0.39(43)$ & 0.004 & $2.06(1.25-3.4)$ & Synonymous & A608 & $\begin{array}{l}\text { No } \\
\text { functional } \\
\text { change }\end{array}$ \\
\hline$A B C A 7$ & rs3752237 & 19:1047161 & $\mathrm{G}>\mathrm{A}$ & 0.68 & $0.46(142)$ & $0.29(32)$ & 0.001 & $2.42(1.46-4.02)$ & Synonymous & G617 & $\begin{array}{l}\text { No } \\
\text { functional } \\
\text { change }\end{array}$ \\
\hline$A B C A 7$ & rs4147915 & 19:1049305 & $\mathrm{C}>\mathrm{A}$ & 0.18 & $0.11(34)$ & $0.2(22)$ & 0.010 & $0.4(0.2-0.8)$ & Synonymous & V807 & $\begin{array}{l}\text { No } \\
\text { functional } \\
\text { change }\end{array}$ \\
\hline$C D 33$ & rs35112940 & $19: 51738917$ & $G>A$ & 0.16 & $0.17(53)$ & $0.25(28)$ & 0.033 & $0.53(0.3-0.95)$ & Missense & G304R & $\begin{array}{l}\text { Possibly } \\
\text { damaging * }\end{array}$ \\
\hline
\end{tabular}

This article is protected by copyright. All rights reserved. 
Table 8. Burden analysis results for known neurodegenerative genes. Burden analysis results from SKAT-O are shown here for (a) Familial AD genes; (b) LOAD-specific genes from GWAS and NGS studies; (c) Familial genes in other neurodegenerative diseases. The total numbers of markers within genes are shown, together with number of coding variants and the number of markers used for burden testing. The $p$-value signifies the association of multiple markers with AD. SKAT-O accounts for markers that show effects in both risk and protective directions.

\begin{tabular}{|c|c|c|c|c|c|}
\hline & Gene & $\begin{array}{c}\text { Total } \\
\text { Variants }\end{array}$ & $\begin{array}{c}\text { Coding } \\
\text { Variants }\end{array}$ & $\begin{array}{c}\text { Number of } \\
\text { Variants Tested }\end{array}$ & P-value \\
\hline \multirow{3}{*}{$\begin{array}{l}\text { (a) } \\
\text { Familial } \\
\text { AD genes }\end{array}$} & $A P P$ & 10 & 1 & 1 & 0.61 \\
\hline & PSEN1 & 4 & 2 & 2 & 1.00 \\
\hline & PSEN2 & 7 & 4 & 4 & 0.83 \\
\hline \multirow{13}{*}{$\begin{array}{l}\text { (b) LOAD } \\
\text { genes }\end{array}$} & $A B C A 7$ & 48 & 28 & 28 & 0.59 \\
\hline & $A P O E$ & 4 & 4 & 4 & 0.06 \\
\hline & BIN1 & 17 & 6 & 6 & 0.25 \\
\hline & CASS4 & 11 & 7 & 7 & 0.32 \\
\hline & $C D 2 A P$ & 9 & 4 & 4 & 0.58 \\
\hline & $C D 33$ & 4 & 4 & 4 & 0.77 \\
\hline & CELF1 & 4 & 3 & 3 & 1.00 \\
\hline & $C L U$ & 5 & 5 & 5 & 0.02 \\
\hline & CR1 & 17 & 9 & 9 & 0.31 \\
\hline & $E P H A 1$ & 15 & 10 & 9 & 0.14 \\
\hline & FERMT2 & 7 & 3 & 3 & 0.86 \\
\hline & INPP5D & 6 & 2 & 2 & 0.54 \\
\hline & $M S 4 A 6 A$ & 8 & 5 & 5 & 0.39 \\
\hline
\end{tabular}

This article is protected by copyright. All rights reserved. 


\begin{tabular}{|c|c|c|c|c|c|}
\hline & NME8 & 16 & 8 & 8 & 1.00 \\
\hline & PICALM & 11 & 3 & 3 & 0.63 \\
\hline & PTK2B & 35 & 17 & 16 & 0.44 \\
\hline & RIN3 & 11 & 9 & 9 & 1.00 \\
\hline & $S L C 24 A 4$ & 22 & 8 & 8 & 0.69 \\
\hline & SORL1 & 29 & 16 & 16 & 0.05 \\
\hline & TREM2 & 4 & 4 & 3 & 0.23 \\
\hline & ZCWPW1 & 9 & 7 & 6 & 0.71 \\
\hline & C9orf72 & 11 & 4 & 4 & 0.66 \\
\hline & CHMP2B & 5 & 3 & 3 & 0.24 \\
\hline & FUS & 4 & 2 & 2 & 1.00 \\
\hline & GRN & 9 & 3 & 3 & 0.84 \\
\hline (c) Other & LRRK2 & 29 & 20 & 20 & 0.12 \\
\hline neurologic & PARK2 & 13 & 5 & 5 & 0.27 \\
\hline genes & PARK7 & 6 & 1 & 1 & 0.33 \\
\hline & PINK1 & 9 & 4 & 4 & 0.88 \\
\hline & $P R N P$ & 7 & 4 & 4 & 0.35 \\
\hline & $S N C A$ & 8 & 2 & 2 & 0.15 \\
\hline & $V C P$ & 6 & 2 & 2 & 0.34 \\
\hline
\end{tabular}

This article is protected by copyright. All rights reserved. 